\title{
Testing the Weak Form of Efficient Market Hypothesis: Empirical Evidence from Equity Markets
}

\author{
Rui Dias, Paula Heliodoro, Nuno Teixeira*, Teresa Godinho \\ Department of Accounting and Finance, Business School of Setúbal, Setúbal, Portugal \\ Email address: \\ rui.dias@esce.ips.pt (R. Dias), paula.heliodoro@esce.ips.pt (P. Heliodoro),nuno.teixeira@esce.ips.pt (N. Teixeira), \\ teresa.godinho@esce.ips.pt (T. Godinho) \\ ${ }^{*}$ Corresponding author
}

\section{To cite this article:}

Rui Dias, Paula Heliodoro, Nuno Teixeira, Teresa Godinho. Testing the Weak Form of Efficient Market Hypothesis: Empirical Evidence from Equity Markets. International Journal of Accounting, Finance and Risk Management. Special Issue: Perspectives on Risk Management and Impact on Sustainability of Companies. Vol. 5, No. 1, 2020, pp. 40-51. doi: 10.11648/j.ijafrm.20200501.14

Received: December 24, 2019; Accepted: January 2, 2020; Published: March 10, 2020

\begin{abstract}
The aim of this paper is to analyse integration and test the hypothesis of an efficient market, in its weak form, in sixteen international financial markets. The sample covers the period from January 2002 to July 2019 and is divided into three sub-periods. In order to achieve such an analysis, the aim is to provide answers to two questions. Has the global financial crisis intensified the financial integration of international markets? If there is a process of mean-reversion in the international stock markets, with arbitrage, the hypothesis of portfolio diversification will be feasible? The results suggest that the global financial crisis has intensified the integration level of international financial markets. Regarding random walk and market efficiency hypotheses, in its weak form, the results suggest the existence of a mean-reversion and the rejection of the hypothesis of information efficiency, in its weak form, in developed and emerging markets, European and non-European. In terms of portfolio diversification analysis, we see that levels of financial integration decreased significantly in the sub-period following the global financial crisis, namely with its respective benchmarks, such as the US market, Japan and Hong Kong. We can assess the existence of feasible diversification opportunities in the long term.
\end{abstract}

Keywords: Financial Integration, Randow Walk Hypothesis, Arbitration, Portfolio Diversification

\section{Introduction}

In the last few decades, globalization phenomenon has shown that correlation between international financial markets has increased significantly, particularly among developed markets. The authors Forbes and Rigobon [1] suggest that links between international stock markets may be strong in quiet and crisis periods, which may limit the possibility of portfolio diversification.

Financial turbulence is a very significant social feature, as a financial crisis may, directly or indirectly, affect the level of economic well-being of a country's inhabitants. If a particular financial market is synchronized with another country's market, the financial soundness of the former somewhat depends on the second's financial stability. The market integration situation may have significant implications for international portfolios diversification [2].
Different studies have analysed the issue of market efficiency, by examining the profitability predictability hypothesis, by analyzing the mean-reversion of the financial markets prices [3]. Whenever the chances of random walk and informational efficiency are rejected, it causes extreme co-movements in stock prices. The event of these phenomena could possibly reduce the implementation of strategies for the efficient portfolios diversification [4, 5].

This essay aims to analyze the integration, as well as to test the efficient market hypothesis, in its weak form, in sixteen international financial markets. The sample comprises the period from January 2002 to July 2019, partitioned into three subperiods.

The analysis aims to answer two questions. Has the global financial crisis intensified the financial integration of international markets? Will the hypothesis of portfolio diversification be feasible, in the context of the process of mean-reversion in international stock markets, with 
arbitrage?

The results suggest that the global financial crisis has intensified the level of integration of international financial markets. In relation to the chances of random walk and market efficiency, in its weak form, the results show the existence of mean-reversion and the rejection of the hypothesis of informational efficiency in developed and emerging markets, European and non-European. Financial integration levels decreased significantly in the subperiod following the global financial crisis, notably with benchmarks such as the US, Japan and Hong Kong. In a first analysis, we can infer the existence of feasible diversification opportunities in the long term.

This research provides two relevant contributions to the literature. The first contribution refers to the study of integration and mean-reversion in developed, European and non-European markets, but also in emerging markets, with the aim of understanding the different predictability between them. As far as we know, the authors Tiwari and Kyophilavong, Hamid, Suleman, Ali Shah and Imdad Akash, Singh and Kumar, Rehman, Chhapra, Kashif and Rehan, Rehman et al., Durusu-Ciftci, Ispir and Kok, Sadat and Hasan and Malafeyev et al. [6-10, 5, 4], analyzed meanreversion in financial market prices, testing the random walk and efficient market hypotheses, in its weak form, the approach being, however, essentially different from the one followed in this test.

The second contribution is related to the sample partition in three subperiods. With this dynamic it was possible to analyze the different predictability considering the behavior of financial markets, falling or rising, as well as the effect of the global financial crisis on international financial markets, in a context of portfolio diversification. In corroboration this essay approached this subject differentiating itself from the authors [11, 12, 14-16].

In terms of structure, this essay is organized into 5 sections. After this first section, the introduction, in Section 2 , presents an analysis of the state of the art, regarding articles on integration and random walk hypothesis in international financial markets. Section 3 describes the methodology. Section 4 contains the data and results. Finally, the main conclusions are shown in section 5 .

\section{Theoretical Framework}

Understanding international links between financial markets in financial crisis periods matters for investors, fund managers and academics in many ways, particularly on the subject of portfolio diversification [17].

According to the authors Mensah and Premaratn [18], due to the extinction of barriers to investment in recent years, many countries have undergone an integration process, both financially and economically. Because of this, the benefits of international diversification have been called into question, mainly due to the various financial crises that have plagued international financial markets.

\subsection{Financial Integration into Financial Markets}

As part of financial markets integration, investors generally seek to include their assets in portfolios that have low correlations, with the purpose of enhancing the benefits of diversification.

In the same context, Grubel and Levy and Sarnat $[19,20]$ argued that investment in international stock markets is motivated by the fact that the correlation between assets is lower than that observed in domestic assets. Therefore, the low correlation among international stock markets is the key factor of international diversification. However, this correlation is dynamic over time, which affects the concept of risk reduction.

In the last few decades, globalization has contributed to increase the correlation among international financial markets. olnik, Boucrelle and Le Fur [21] suggested that correlations among assets have not increased. King, Sentana and Wadhwani [22] achieved similar results by examining links amongst international markets. Forbes and Rigobon [1] argued that synchronization amongst international stock markets might be strong during quiet periods, as well as during periods of crisis, which may call into question some diversification benefits.

The integration amongst developed countries' stock markets is robust and has been indicated significant increases. This leads investors to observe stock markets, in the expectation that correlations are weak between developed and emerging markets. Various empirical works, such as, Driessen and Laeven, Chang, Chen, Chi and Young and Gupta and Donleavy [23-25], addressed the issue of investments in emerging markets being made by investors from developed countries.

Khan and Kenourgios, and Samitas [11, 26], examined international financial markets and compared it with the U.S. market in a co-integration context. Khan [11] analyzed 23 financial markets, testing the hypothesis of portfolios diversification. The results showed that stock indices that had the lowest integration with the U.S. market were those that contained the highest probability of obtaining gains, through portfolio diversification, during the 2008 financial crisis period. Kenourgios and Samitas [26] tested the emerging markets of the Balkans, the United States, and Europe's developed markets during the period 2000-2009. The results suggest long-term links among markets, as well as significant correlations among stock markets, during the 2008 global financial crisis. The authors show that their findings have relevant implications for portfolio diversification.

Horvath and Petrovski and Gjika and Horváth [12, 27], examined the integration of European financial markets with the purpose of testing the hypothesis of regional portfolios diversification. Horvath and Petrovski [12] evaluated the stock markets in Western and South-East Europe during the period 2006-2011. The results showed low levels of integrations, except for Croatia, which is in line with Western Europe. Gjika and Horváth [27] investigated the financial markets of Central Europe and the Eurozone over the period 
2001-2011. The authors argue that market integration is significant. These results have important implications for portfolio diversification in periods of great instability. Alotaibi and Mishra

Abu-Alkheil et al., Alotaibi and Mishra and Ferreira, Dionísio and Movahed [28-30], assessed international markets financial integration. Abu-Alkheil et al. [28] examined 32 Islamic stock markets and 32 conventional stock indexes in the period 2002-2014. The results suggest the lack of financial integration among the 31 Islamic indices, except for the Pakistan market. The authors corroborate the hypothesis that portfolio diversification is robust in these financial markets. Alotaibi and Mishra [29] studied the financial markets of the Persian Gulf in the period 2002-2013. The authors show the existence of significant financial integration, an exception made to the Saudi Arabian market. In view of these results, the possibility of portfolio diversification is not consistent for most of these regional markets. Ferreira, Dionísio and Movahed [30] analyzed 48 financial markets in the context of long memory and integration, from January 1995 to February 2014. The authors argue that there are 170 pairs of co-integrated markets, which could question the possibility of portfolio diversification.

\subsection{The Efficient Market Hypothesis, in Its Weak Form}

The efficient market hypothesis (EMH) argues that bond prices reflect all available information and that investors cannot obtain anomalous profitability trading based on this information. EMH is an essential concept for financial institutions, individual and institutional investors and government regulators. An investor's deal strategy is greatly influenced by market efficiency. Market efficiency also determines the regulatory measures that must be developed to ensure the development and organized management of a country's markets [31, 32].

Different studies have addressed the issue of market efficiency, by analyzing the hypothesis of profitability predictability, through the analysis of stock prices meanreversion patterns, inspired by seminal work of Poterba and Summers and Fama, and French [33, 34], that documented mean-reversion in stock markets yields, in time horizons greater than one year.

This theme has motivated other studies to analyze the implications, in the event of market efficiency, according to which assets' current price reflects all available information at any given time, quickly adjusting, as new and unforeseen information comes. The mean-reversion hypothesis, also known as a negative serial correlation, has been interpreted as an efficient correction mechanism in developed markets and a speculative bubble sign in emerging financial [35, 34].

Financial markets globalization has led academics to develop several studies on the mean-reversion hypothesis in regional markets, such as Latin America (Urrutia; Grieb and Reyes; Charles and Darné) [36-38], Africa (Magnusson and Wydick; Smith, Jefferis and Ryoo) [39, 40], Asia (Huang; Groenewold and Ariff; Kim and Shamsuddin) [41-43],
Middle East (Abraham, Seyyed and Alsakran; Al-Khazali, Ding and Pyun) [44, 45], Europe (Smith and Ryoo; Worthington and Higgs; Smith; Borges) [46-49] and in international financial markets (Amira, Taamouti and Tsafac; Tiwari and Kyophilavong; Hamid, Suleman, Ali Shah and Imdad Akash) [50, 6, 7]. S. Nisar and M. Hanif,

Nisar and Hanif, Mehla and Goyal, El Khamlichi, Sarkar, Arouri and Teulon, Hamid, Suleman, Ali Shah and Imdad Akash, [51, 53, 7], tested random walk and efficient market hypothesis, in its weak form, in Asian markets.

Nisar and Hanif [51] examined major southern Asian stock exchanges, including India, Pakistan, Bangladesh and Sri Lanka. They analyzed daily, weekly and monthly historical data in the period 1997-2011. The results suggest that South Asian stock markets reject the random walk hypothesis, evidencing market inefficiency in its weak form.

Mehla and Goyal [52] examined India's stock market. The results suggest that the market does not show the characteristics of random walk and, as such, is not efficient in its weak form, in daily and weekly profitability. El Khamlichi, Sarkar, Arouri and Teulon [53] tested the Islamic indices, comparing them with the benchmarks Dow Jones and S\&P. The authors suggest that Islamic indices have the same level of (in) efficiency as benchmarks. However, MSCI and FTSE indices are less inefficient. Additionally, Islamic indices and benchmarks are not integrated, suggesting that long-term diversification opportunities exist.

Hamid, Suleman, Ali Shah and Imdad Akash [7] analyzed the financial markets of Pakistan, India, Sri Lanka, China, Korea, Hong Kong, Indonesia, Malaysia, Philippines, Singapore, Thailand, Taiwan, Japan and Australia, from January 2004 to December 2009. The authors suggest that prices do not follow the random walk hypothesis in AsiaPacific region countries. Furthermore, investors can benefit from the arbitrage process, achieving anomalous profitability, without incurring in additional risk.

Gimba, McKerrow, N'Dri, Abakah, Alagidede, Mensah and Ohene-Asare [54-57], tested the chances of random walk hypothesis in African markets. Gimba [54] studied the Nigerian Stock Exchange (NSE), analyzed daily data from January 2007 to December 2009, and weekly data from June 2005 to December 2009. The author suggests that the NSE stock market is inefficient in its weak form. Considering empirical evidence, there might be anomalies in stocks' profitability. McKerrow [55] evaluated the markets of Botswana, Côte d'Ivoire, Ghana, Mauritius and Namibia. The results suggest mixed results in market efficiency in its weak form. N'Dri [56] analyzed the regional markets of The Economic and Monetary Union of West Africa (BRVM) from January 2002 to December 2004. The results suggest that random walk hypothesis cannot be rejected, evidencing that BRVM markets are efficient in its weak form. Abakah, Alagidede, Mensah e Ohene-Asare [57] examined the markets of South Africa, Nigeria, Egypt, Ghana and Mauritius during the period 2000-2013. The authors suggest mixed results, arguing that used methodology may indicate different results. 
Shirvani and Delcoure, Ngene, Tah and Darrat [32, 58], questioned whether stock prices follow random walk or mean-reversion processes in international markets. Shirvani and Delcoure [32] analysed 16 OECD markets. The authors show that markets are efficient, because the mean-reversion hypothesis was not rejected. Ngene, Tah and Darrat [58] examined 18 emerging markets in the presence of multiple unforeseen and successive structural breaks. When using single-break tests, the random walk hypothesis is rejected. However, using double-level change tests on average, with due tolerance to various structural breaks, the results are consistent with random walk hypothesis, in most markets.

Aggarwal, Rehman, Chhapra, Kashif and Rehan, Malafeyev, Awasthi, S. Kambekar and Kupinskaya [59, 9, 4], examined market efficiency, in its weak form, in Asian financial markets. Aggarwal [59] analyzed the price index of Korea shares from July 1997 to September 2016. The author shows that the series do not follow a random walk model. The results have significant implications for investors, as market inefficiency can affect domestic and international flows in an economy. Rehman, Chhapra, Kashif and Rehan [9] analyzed the indices KSE 100, S \& P BSE 500 and CSE All Share. The results suggest that the random walk process and efficiency hypothesis, in its weak form, do not occur. This study examines the concept of random walk, considering only stock markets, ignoring other financial markets. Malafeyev, Awasthi, S. Kambekar and Kupinskaya [4] studied the stock markets of China and India, analyzing the impact of the global financial crisis of 2008 and the recent Chinese crisis of 2015. They selected data from the last 20 years of the Bombay Stock Exchange (BSE200) and the Shanghai Stock Exchange Composite Index, divided the data into four sub periods, i.e., before the financial crisis (period I), during the 2008 financial crisis (period II), after the subprime crisis, before the Chinese crisis (period III) and from the beginning of the Chinese crisis to date (period IV). The evidence confirms that the Indian and Chinese stock market do not show market efficiency in its weak form. These markets do not follow the random walk hypothesis in the first three periods (1996 until 2015), although efficiency, in percentage, evidences an increase trend after the 2008 global financial crisis.

\section{Empirical Study}

To estimate time series stationarity for the sixteen financial markets, we will use the ADF - Augmented Dickey-Fuller, KPSS - Kwiatkowski, Phillips, Schmidt an Shinb, PP Perron and Phillips tests. Additionally, to corroborate the analysis, the Clemente et al. test [4], with the intention of studying the existence or not of structure breaks in the sixteen stock indexes. In order to evaluate the level of financial integration, we will carry out the co-integration test of Gregory e Hansen [60], as well as the test of Wright [61], with the purpose of evaluating the random walk hypothesis in time series profitability.

The purpose of using opposing null hypotheses tests is to mitigate the fact that ADF tests [62] and KPSS [63] have low power, when compared with econometric methodologies that postulate structure breakdowns [64]. In addition, Noman e Rahman [65] when examining time series stationarity, corroborate the idea that the results of linear unit root tests (such as ADF and KPSS) can lead to inaccurate results, when used in time series that present structure breaks.

In addition to ADF, PP and KPSS stationarity tests, we will use Clemente et al. methodology [66]. This test allows the identification of any structural breaks, as well as the year of its occurrence. In particular, structural breakdown leads to a significant change in the level and/or trend of a timeseries, a change that may have a stable or momentary character. If the series is stationary, shocks should have temporary effects on, otherwise, they will have permanent effects, i.e. they do not recover the initial level.

Thus, structural breaks evaluations in this essay are essential to make inferences about the effects and its implications, such as the period in which they occur. Spurious results are thus avoided, such as rejecting a unit root null hypothesis, when in fact the series is under the effect of a structural break. All this reasoning is corroborated by several empirical works, particularly the authors Perron and Andreou and Ghysels [67-68].

The modeling of structural breaks in cointegrated processes has been a theme widely studied in recent years. The reason why standard cointegration tests such as Engle and Granger and Johansen [69-70] are not suitable for testing cointegration with regime change is that such tests assume cointegration vector as invariant in time.

Using a VAR model (self-regressive vector), Seo [71] drifts a LM test (Lagrange multiplier) for structural breaks, while Inoue [72] derives a test for cointegrated break processes. In a distinct way, cointegration models were developed with structural breaks, such as the case of recursive estimation used by Hansen e Johansen [73] and the combination of cointegration with Markovian processes formulated by Krolzig [74]. Hansen [75] derives a statistic by maximum likelihood that asymptotically distributed as a Chisquare distribution, to test structural breaks for known time points. This study looked at the U.S. interest rate and found evidence of regime change, coinciding with the U.S. central bank's economic policy change in September 1979 and October 1982.

This essay will carry out cointegration tests with structural break through the Gregory and Hansen methodology [76]. In that empirical study, the authors were concerned about a general test model, in which the cointegration vector varies over time. The method developed by Gregory and Hansen [76] is considered to be a complement to the ADF test, in the econometric perspective, as a multivariate version of the Zivot and Andrews [77]. According to the authors, the existence of structural breaks can lead to erroneous conclusions around the acceptance of the null hypothesis of non-cointegration and, therefore, the absence of any type of long-term relationship among variables $I(1)$.

The variance ratio is given by the relationship between 
variance of $q$ periods and of a single period, being the same equal to 1: Thus, in the test of the variance ratio, under the null hypothesis $V R(q)=1$, the series follows a random walk type process. When the randomness hypothesis is rejected and $\operatorname{VR}(q)>1$, the series indicates the existence of positive correlation. When the null hypothesis is rejected and $V R(q)<$ 1 , the series evidences negative serial correlation. Lo e Mackinlay [78] developed asymptotic distribution techniques, in order to test the null hypothesis of profitability randomness, assuming the occurrence of random shocks i.i.d., described by gaussian distribution. The variance test developed by Lo e Mackinlay [78] considers asymptotic properties, in the way they express test statistics. To ensure this restriction, Wright [61] developed a non-parametric version of the variance test to test the random walk hypothesis in exchange rates series. According to this author, this version has advantages over the parametric version. On the one hand, by not requiring a asymptotic approach, the question of the size of the sample becomes minor. On the other hand, nonparametric tests show superior performance in serial correlation detection, especially when the series do not exhibit normality.

In this essay, we considered a non-parametric test developed by Wright [61], because it is a more resilient test to time series that do not display normality and quite consistent when it have serial correlation. The methodology of this author consists of two types of tests, the position test (Rankings) for homoscedastic series and the Test of Signals for heteroscedastic series.

Variance position test is supported by ordering the profitability series. It is considered to be $r\left(r_{t}\right)$ as the position of profitability, $r_{t}$, among $r_{1}, r_{2}, \ldots, r_{T}$ :

$$
\begin{aligned}
& r_{1 t}^{\prime}=\frac{\left(r\left(r_{t}\right)-\frac{T+1}{2}\right)}{\sqrt{\frac{\frac{(T-1)(T+1)}{2}}{12}}} \\
& r_{2 t}^{\prime}=\Phi^{-1}\left(\frac{r\left(r_{t}\right)}{T+1}\right)
\end{aligned}
$$

In which $\Phi^{-1}$ is the cumulative reverse standardized normal distribution, $r_{2 t}^{\prime}$ is a standardized linear transformation of profitability position and $r_{2 t}^{\prime}$ is a standardized reverse normal transformation.

$$
\begin{aligned}
& R_{1}(q)=\left(\frac{\frac{1}{T q} \sum_{t=q+1}^{T}\left(r_{1 t}^{\prime}+r_{1 t-1}^{\prime}+\cdots+r_{1 t-q}^{\prime}\right)^{2}}{\frac{1}{T} \sum_{t=q+1}^{T}\left(r_{1 t}^{\prime}\right)^{2}}\right) \times\left(\frac{2(2 q-1)(q-1)}{3 q T}\right)^{-1 / 2} \\
& R_{2}(q)=\left(\frac{\frac{1}{T q} \sum_{t=q+1}^{T}\left(r_{2 t}^{\prime}+r_{2 t-1}^{\prime}+\cdots+r_{2 t-q}^{\prime}\right)^{2}}{\frac{1}{T} \sum_{t=q+1}^{T}\left(r_{2 t}^{\prime}\right)^{2}}\right) \times\left(\frac{2(2 q-1)(q-1)}{3 q T}\right)^{-1 / 2}
\end{aligned}
$$

The rejection of the random walk hypothesis of profitability is generated by a simulation process, in which the values of the statistics $r_{1 t}^{\prime}$ e $r_{2 t}^{\prime}$ are replaced by simulated values $r_{1 t}^{\prime *}$ e $r_{2 t}^{\prime *}$. Using bootstrap estimates, which result in successive and random data generation, in order to simulate the statistical properties of the true sample distribution, the exact distribution of $R_{1}(q)$ and $R_{2}(q)$ can be approximated to a certain level of confidence.

The methodology of [61], proposes a second test, called a ratio of variances by signals, which considers the sign of the yields, $r_{t}$, to calculate the signal ratio, being the same heteroscedastic, so we can use the following test statistic:

$S_{1}(q)=\left(\frac{\frac{1}{T q} \sum_{t=q+1}^{T}\left(S_{t}+S_{t-1}+\cdots+S_{t-q}\right)^{2}}{\frac{1}{T} \sum_{t=q+1}^{T}\left(S_{t}\right)^{2}}\right) \times\left(\frac{2(2 q-1)(q-1)}{3 q T}\right)^{-1 / 2}$

Where

$$
\begin{gathered}
S_{t}=2 v\left(r_{t}, 0\right) \\
v\left(x_{t}, p\right)=\left\{\begin{array}{c}
0,5 \text { se } x_{t}>p \\
-0,5 \text { se } x_{t} \leq p
\end{array}\right.
\end{gathered}
$$

The distribution of $S_{1}(q)$ can be approximated through $S_{1}^{*}(q)$ using bootstrap techniques, as happened in the variance ratio by rankings. $S_{1}^{*}(q)$ is obtained from the sequence $\left\{S_{t}^{*}\right\}_{t=1}^{T}$, as each of its elements to be able to record the values 1 or -1 , with the same probability.

\section{Data and Results}

\subsection{Data}

In order to analyze financial integration and meanreversion, we selected sixteen international financial markets in Europe, Asia, Latin America and the US Data on the daily price indices of the various markets were obtained from the DataStream platform, all quotes are in local currency, with the intention of mitigating the exchange rate risk.

The yields are daily and cover the period from 1 January 2002 to 4 July 2019 (4568 observations). We chose to divide the sample into three subperiods, one pre - CFG (Global Financial Crisis) corresponding to the subperiod from 1 January 2002 to 31 July 2007, one of crisis, which we call the Global Financial Crisis covering the subperiod from 1 August 2007 to 14 December 2014 and a third subperiod containing the time lapse from 1 January 2015 to 4 July 2019, which we call for post subperiod - CFG.

With regard to the start of CFG on 1 August 2007 it is supported by the study of Gallegati [79], who recognizes "... the explosion of the U.S. subprime mortgage bubble was in August 2007 (crisis consensus date)". In corroboration, Horta, Mendes and Vieira, and Phillips and Yu [80-81] also found evidence that the real estate price bubble emerged in August 2007.

With regard to dating the start of CFG on 1 August 2007 it is supported by the study of Phillips and $\mathrm{Yu}$ [81] which highlights the date of the break in August 2007 as the beginning of the crisis. See also Banco BNP Paribas, which closed two mutual funds exposed to the subprime crisis, which was seen by markets as a significant event [80].

Table 1. Countries and price indices.

\begin{tabular}{llll}
\hline Country name & Index & Country name & Index \\
\hline BELGIUM & BEL 20 & JAPAN & NIKKEI 225 \\
BRAZIL & BOVESPA & MALAYSIA & BURSA \\
CHINA & SHANGAI & MEXICO & IPC \\
FRANCE & CAC 40 & PHILIPPINE & PHILIPPINE \\
GERMANY & DAX 30 & PORTUGAL & PSI 20 \\
\hline
\end{tabular}




\begin{tabular}{llll}
\hline Country name & Index & Country name & Index \\
\hline GREECE & ATHEX & SPAIN & IBEX 35 \\
HONG-KONG & HANG SENG & THAILAND & SET \\
IRELAND & ISEQ & USA & NYSE \\
\hline
\end{tabular}

Source: own elaboration.
Figure 1 shows the evolution of price indices, in first annual differences, from the sixteen markets under analysis. The price indices represented clearly reveal a growth period (2002-2006), a time break of great turbulence (2007-2009), and a third period with rises and declines (2010-2019).

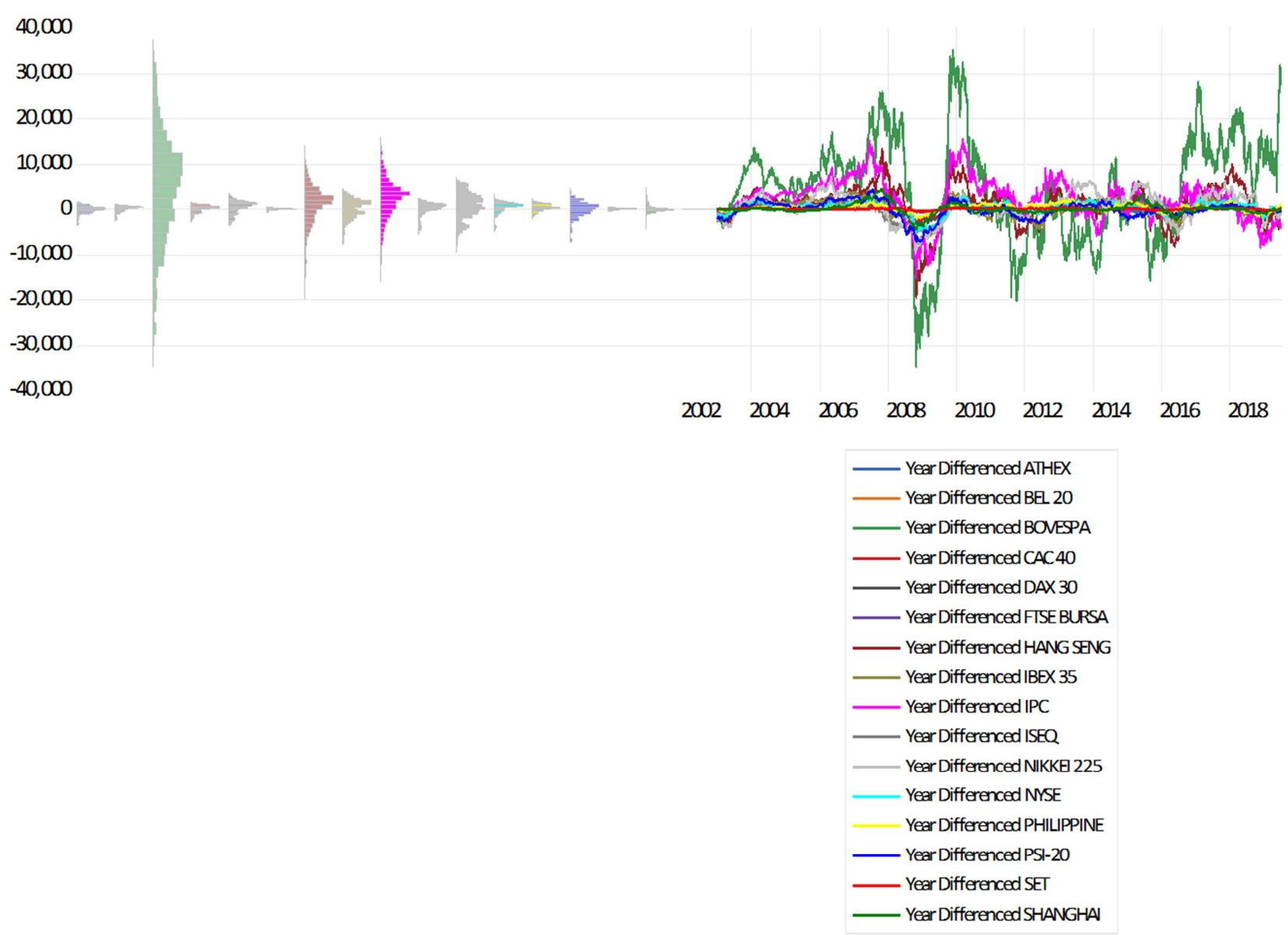

Note: DataStream: $1^{\text {st }}$ January 2002, 4567 point data.

Figure 1. Evolution, in first differences, of the 16 financial markets, in the full period.

Tables 2 and 3 shows the main descriptive statistics of profitability, as well as the Jarque-Bera adherence test of the sixteen financial markets under study.

Descriptive statistics analyses allow to assess that most indices have positive average daily yields, except for ATHEX and PSI 20 indices. On the other hand, all profitability series showed signs of deviation from the normal hypothesis, meeting the coefficients of asymmetry and kurtosis. The analyzed series are leptokurtic and have asymmetric tails. The characteristic of negative asymmetry is verified in fifteen indexes, with emphasis for the BURSA $(-0.87)$ and SET (0.84 ) indices. Additionally, the coefficients of asymmetry and kurtosis are statistically different from those of a normal distribution. The resulting series analyzed are leptokurtic and asymmetric.

Table 2. Descriptive statistics of the 16 financial markets, profitability, full period.

\begin{tabular}{|c|c|c|c|c|c|c|c|c|}
\hline & ATHEX & BEL 20 & BOVESPA & BURSA & CAC 40 & DAX 30 & HANG SENG & IBEX 35 \\
\hline Mean & -0.000233 & 5.99E-05 & 0.000440 & 0.000198 & 4.27E-05 & 0.000196 & 0.000204 & $2.47 \mathrm{E}-05$ \\
\hline Std. Dev. & 0.017912 & 0.012185 & 0.016758 & 0.006978 & 0.013894 & 0.014206 & 0.013737 & 0.014106 \\
\hline Skewness & -0.379357 & -0.044377 & -0.097964 & -0.865442 & -0.008920 & -0.009221 & -0.003407 & -0.082008 \\
\hline Kurtosis & 10.72753 & 9.553991 & 7.849508 & 15.91269 & 9.031823 & 8.303070 & 13.18240 & 10.41478 \\
\hline Jarque-Bera & $11472.76 * * *$ & $8175.44 * * *$ & $4482.53 * * *$ & $32298.88 * * *$ & $6923.42 * * *$ & $5351.55 * * *$ & $19729.70 * * *$ & $10467.16^{* * *}$ \\
\hline Observations & 4567 & 4567 & 4567 & 4567 & 4567 & 4567 & 4567 & 4567 \\
\hline
\end{tabular}

Note: $* * *$. $* *$ represents significance at 1 and $5 \%$, respectively.

Source: own elaboration. 
Table 3. Descriptive statistics of the 16 financial markets, profitability, full period (Cont.).

\begin{tabular}{|c|c|c|c|c|c|c|c|c|}
\hline & IPC & ISEQ & NIKKEI 225 & NYSE & PHILIPPINE & PSI 20 & SET & SHANGAI \\
\hline Mean & 0.000419 & $2.56 \mathrm{E}-05$ & 0.000158 & 0.000165 & 0.000423 & $-8.92 \mathrm{E}-05$ & 0.000379 & 0.000133 \\
\hline Std. Dev. & 0.011653 & 0.013525 & 0.014313 & 0.011772 & 0.011912 & 0.011492 & 0.011877 & 0.015386 \\
\hline Skewness & 0.026198 & -0.678310 & -0.477374 & -0.378570 & -0.561788 & -0.269763 & -0.838983 & -0.428104 \\
\hline Kurtosis & 9.674367 & 12.17514 & 10.78578 & 14.27031 & 10.73958 & 10.09685 & 17.46806 & 8.106823 \\
\hline Jarque-Bera & $8477.48 * * *$ & $16369.58 * * *$ & $11708.63 * * *$ & $24279.93 * * *$ & $11638.92 * * *$ & $9639.49 * * *$ & $40368.54 * * *$ & $5102.24 * * *$ \\
\hline Observations & 4567 & 4567 & 4567 & 4567 & 4567 & 4567 & 4567 & 4567 \\
\hline
\end{tabular}

Nota: $* * * * *$ represents significance at 1 and $5 \%$, respectively.

Source: own elaboration.

As we are estimating temporal successions, we should examine the stationary nature of the profitability series of the 16 indices under analysis. ADF tests [62], PP [82], postulate the same null hypotheses. While the KPSS test [63] exposes opposite hypotheses. The intersection of unit root tests shows stationarity profitability. However, we must highlight the lags of the tests, which suggest that the time series may not be stable and, in view of this indication we will carry out the test of [66] that analyses stationarity with structure breaks (Tables 4 and 5).

Table 4. Statistical tests of the 16 financial markets, in profitability, full period.

\begin{tabular}{|c|c|c|c|c|c|c|c|c|}
\hline & ATHEX & BEL 20 & BOVESPA & BURSA & CAC 40 & DAX 30 & HANG SENG & IBEX 35 \\
\hline $\mathrm{ADF}$ & $-62.93(0) * * *$ & $-64.21(0)^{* * *}$ & $-68.36(0) * * *$ & $-60.32(0)^{* * *}$ & $-33.81(4) * * *$ & $-68.97(0) * * *$ & $-68.78(0)^{* * *}$ & $-67.21(0) * * *$ \\
\hline PP & $-62.82(9) * * *$ & $-64.17(3)^{* * *}$ & $-68.51(24) * * *$ & $-60.39(3)^{* * *}$ & $-70.79(26) * * *$ & $-69.18(13)^{* * *}$ & $-68.78(2)^{* * *}$ & $-67.63(20) * * *$ \\
\hline KPSS & $0.14(12)$ & $0.09(5)$ & $0.13(24)$ & $0.17(6)$ & $0.11(27)$ & $0.08(14)$ & $0.04(3)$ & $0.07(20)$ \\
\hline
\end{tabular}

Note: In the ADF test we used Lag (Automatic Length based on SIC) in PP (BandWidth (Newey-West automatic) using Bartlett Kernel) in KPSS (BandWidth (Newey-West automatic) using Bartlett Kernel). Lateral values in parentheses refer to lags. ***.**.*represent significance at $1 \%$. 5\% and $10 \%$, respectively. Source: own elaboration.

Table 5. Statistical tests of the 16 financial markets, in profitability, full period (Cont.).

\begin{tabular}{|c|c|c|c|c|c|c|c|c|}
\hline & IPC & ISEQ & NIKKEI 225 & NYSE & PHILIPPINE & PSI 20 & SET & SHANGAI \\
\hline $\mathrm{ADF}$ & $-62.64(0) * * *$ & $-64.84(0)^{* * *}$ & $-69.45(0)^{* * *}$ & $-72.54(0) * * *$ & $-60.46(0) * * *$ & $-62.41(0)^{* * *}$ & $-45.12(1)^{* * *}$ & $-66.84(0) * * *$ \\
\hline PP & $-62.49(28) * * *$ & $-64.79(7)^{* * *}$ & $-69.64(21) * * *$ & $-73.11(19) * * *$ & $-60.14(23)^{* * *}$ & $-62.28(9)^{* * *}$ & $-67.01(16)^{* * *}$ & $-66.99(15)^{* * *}$ \\
\hline KPSS & $0.49(25)^{* *}$ & $0.22(6)$ & $0.09(22)$ & $0.06(22)$ & $0.10(18)^{* * *}$ & $0.08(5)$ & $0.14(16)$ & 0.07 \\
\hline
\end{tabular}

Note: In the ADF test we used Lag (Automatic Length based on SIC) in PP (BandWidth (Newey-West automatic) using Bartlett Kernel) in KPSS (BandWidth (Newey-West automatic) using Bartlett Kernel). Lateral values in parentheses refer to lags. ***. **.*represent significance at $1 \%$. 5\% and $10 \%$, respectively. Source: own elaboration.

The test of Clemente et al. [66] identified structure breaks in the three subperiods. These results are mainly due to the financial crises leading up to the 2008 crisis. After the growth of stock market indices, in the second half of the 1990 s, there was a fall, as a result of the crisis of technology companies (Dot-com crisis). Table 6 shows the most significant structure breaks of the Pre - CFG subperiod and we easily verify the existence of two trends. The first is related to the Dot-com financial crisis, namely the ATHEX, BEL 20, BOVESPA, CAC 40, DAX 30, HANG SENG, IBEX 35, IPC, ISEQ, NIKKEI 225, NYSE and PSI 20 indices. Whilst the second trend is synchronized with subprime product defaults (CDS's and ABS), resulting in a lack of liquidity and confidence in financial markets.

Table 6. Unit root tests with structural breaks, for the yields of the 16 financial markets in the Pre - CFG subperiod.

\begin{tabular}{lllll}
\hline Index & t-stat & Break Date & Index & t-stat \\
\hline ATHEX & $-36.09(0)^{* * *}$ & $31 / 03 / 2003$ & Break Date & $-35.93(0)^{* * *}$ \\
BEL 20 & $-36.24(0)^{* * *}$ & $14 / 03 / 2003$ & IPC & $-36.23(0)^{* * *}$ \\
BOVESPA & $-37.66(0)^{* * *}$ & $22 / 07 / 2002$ & NIKEQ & $-38.78(0)^{* * *}$ \\
BURSA & $-33.41(0)^{* * *}$ & $05 / 03 / 2007$ & NYSE & $-39.81(0)^{* * *}$ \\
CAC 40 & $-39.91(0)^{* * *}$ & $14 / 03 / 2003$ & $04 / 03 / 2002$ \\
DAX 30 & $-41.22(0)^{* * *}$ & $11 / 10 / 2002$ & PHILIPPINE & $-34.54(0)^{* * *}$ \\
HANG SENG & $-37.27(0)^{* * *}$ & $29 / 04 / 2003$ & PSI 20 & $-36.57(0)^{* * *}$ \\
IBEX 35 & $-39.93(0)^{* * *}$ & SET & $-41.57(0)^{* * *}$ & $-302 / 07 / 2002$ \\
\hline
\end{tabular}

Note: Lag Length (Sic-based Auto Length). Break Selection: Minimize Dickey-Fuller's t-statistic. Lateral values in parentheses refer to lags. ***. **. *represent significance at $1 \% .5 \%$ and $10 \%$, respectively.

Source: own elaboration.

With the 2008 crisis everything changed, the lack of confidence, turbulence and pessimism experienced in financial markets has led to chaos in international markets. Additionally, risk aversion was so present in the behavior of institutional investors that it led to a massive flight of stock market investors and a reinvestment in bond markets. These portfolio rebalancing led to a lack of liquidity in stock markets, causing shocks in all sectors and, consequently, 
infecting financial markets on a global scale (Tables 7 and 8).

Table 7. Unit root tests with structural breaks, for the yields of the 16 financial markets in the CFG sub-period.

\begin{tabular}{llllll}
\hline Index & t-stat & Break Date & Index & t-stat & Break Date \\
\hline ATHEX & $-41.53(0)^{* * *}$ & $24 / 10 / 2008$ & IPC & $-41.59(0)^{* * *}$ & $28 / 10 / 2008$ \\
BEL 20 & $-43.24(0)^{* * *}$ & $16 / 10 / 2008$ & ISEQ & $-43.73(0)^{* * *}$ & $29 / 09 / 2008$ \\
BOVESPA & $-46.15(0)^{* * *}$ & $19 / 09 / 2008$ & NIKKEI 225 & $-45.92(0)^{* * *}$ & $15 / 03 / 2011$ \\
BURSA & $-41.50(0)^{* * *}$ & $10 / 03 / 2008$ & NYSE & $-49.46(0)^{* * *}$ & $20 / 11 / 2008$ \\
CAC 40 & $-46.83(0)^{* * *}$ & $29 / 10 / 2008$ & PHILIPPINE & $-40.00(0)^{* * *}$ & $27 / 10 / 2008$ \\
DAX 30 & $-44.59(0)^{* * *}$ & $28 / 10 / 2008$ & PSI 20 & $-41.71(0)^{* * *}$ & $06 / 10 / 2008$ \\
HANG SENG & $-47.16(0)^{* * *}$ & $27 / 10 / 2008$ & SET & $-44.46(0)^{* * *}$ & $27 / 10 / 2008$ \\
IBEX 35 & $-43.67(0)^{* * *}$ & $22 / 10 / 2008$ & SHANGAI & $-44.88(0)^{* * *}$ & $22 / 09 / 2008$ \\
\hline
\end{tabular}

Note: Lag length (AUTOMATIC length based on SIC). Break Selection: Minimize Dickey-Fuller's t-statistic. Lateral values in parentheses refer to lags. $* * *$. **. *represent significance at $1 \% .5 \%$ and $10 \%$, respectively.

Source: own elaboration.

Table 8. Unit root tests with structural breaks, for the yields of the 16 financial markets in the Post subperiod - CFG.

\begin{tabular}{lllll}
\hline Index & t-stat & Break Date & Index & t-stat \\
\hline ATHEX & $-33.08(0)^{* * *}$ & $03 / 08 / 2015$ & IPC & $-32.16(0)^{* * *}$ \\
BEL 20 & $-32.69(0)^{* * *}$ & $24 / 08 / 2015$ & ISEQ & $-34.62(0)^{* * *}$ \\
BOVESPA & $-35.32(0)^{* * *}$ & $18 / 05 / 2017$ & NIKKEI 225 & $-37.40(0)^{* * *}$ \\
BURSA & $-32.69(0)^{* * *}$ & $30 / 05 / 2018$ & NYSE & $-34.25(0)^{* * *}$ \\
CAC 40 & $-34.15(0)^{* * *}$ & $24 / 08 / 2015$ & $24 / 06 / 2016$ & $-34.25(0)^{* * *}$ \\
DAX 30 & $-34.98(0)^{* * *}$ & $24 / 08 / 2015$ & 2016 & $-30.98(0)^{* * *}$ \\
HANG SENG & $-34.27(0)^{* * *}$ & $08 / 07 / 2015$ & PHILIPPINE & $24 / 08 / 2015$ \\
IBEX 35 & $-35.03(0)^{* * *}$ & $24 / 06 / 2016$ & SET & $22 / 01 / 2015$ \\
\hline
\end{tabular}

Note: Lag length (AUTOMATIC length based on SIC). Break Selection: Minimize Dickey-Fuller's t-statistic. Lateral values in parentheses refer to lags. $* * *$.

**. *represent significance at $1 \% .5 \%$ and $10 \%$, respectively.

Source: own elaboration.

\subsection{Results}

\section{Cointegration and market efficiency}

This test aims to analyze financial integration and test the efficient market hypothesis, in its weak form, in sixteen international financial markets. The variables under analysis are stationary in the first differences, and present structural breakdowns in all markets and in the three subperiods.

In view of the structure breaches verified, we use the methodology of Gregory and Hansen [60], the sample divided into three subperiods. The first subperiod was dedicated to a subperiod of pre-global financial crisis (20022007). The second concerns the global financial crisis (20072014), while the third and final subperiod shows the postglobal financial crisis (2015-2019).

The results of the integration test among markets in the sub-period of the pre-global financial crisis. The results show 89 pairs of integrated markets with structure break (in 240 possible). We easily understand that France and China markets are those that most co integrate with their peers, 10 integrations (in 15 possible). The U.S. market has 9 integrations (out of 15), while Spain, Greece and Mexico financial markets have 7 integrations (in 15 possible). The Stock Exchanges of Germany, Philippines, Japan, Brazil, Malaysia and Portugal have 6, 5 and 4 integrations, respectively. The financial markets of Belgium, Hong Kong and Ireland show 3 integrations with their peers, while Thailand's market has a single integration. These results are in line with the authors Alotaibi and Mishra and Ferreira, Dionísio and Movahed [29-30] studies that show international markets' financial integration.

The results of the integration test among markets in the subperiod of the global financial crisis. The results show 128 pairs of integrated markets with structure break (in 240 possible). It is obvious that the Hong Kong market is the stock index that cointegrates the most with its peers, 13 integrations (out of 15). The markets in Belgium, France and the USA have 12 integrations. As for the financial markets of Ireland, Japan, Greece, Germany and Thailand they have 11, 10, 9 and 8 integrations, respectively. The Stock Exchanges of Portugal, Mexico, the Philippines, China and Spain show 7, 6, 5 and 4 integrations, respectively. The financial markets of Brazil and Malaysia are the indices with the least cointegrations of 2 and 1, respectively. When compared to the previous subperiod we found that, during the global financial crisis, the level of financial integration rose by $44 \%$, i.e. portfolio diversification in the long term decreased significantly. These results are in line with the authors Claessens, Ariccia, Igan and Laeven, Bekaert, Ehrmann, Fratzscher and Mehl, Lin, J. Y., Treichel [83, 84, 85], that show that the financial crisis of 2008 is the first global crisis and the most severe since the Great Depression. Its consequences were not limited to stock markets, but have had very different effects, also contributing to highlight indebtedness and nations economic growth [86].

The results of the integration test between markets in the subperiod of the post-global financial crisis. The results show 99 pairs of integrated markets with structure break (in 240 possible). The financial markets with a higher level of financial integration are the indices of Mexico and Ireland, 
with 15 and 14 co-integrations, respectively (in 15 possible). The Stock Exchanges of Belgium, Portugal, France and the USA have financial integrations with their peers of $13,11,9$ and 7 respectively. The indices of Greece, Germany, Spain, Japan and China have integrations of $6,5,4$, respectively. The markets in Brazil, Hong Kong and Thailand show 3 and 2 integrations with their peers. Malaysian and Philippine markets have no financial integration with other financial markets. When compared to the period of the global financial crisis we understand that the integration level decreased by $30 \%$. Benchmark markets such as the US, Japan and Hong Kong significantly decreased the level of financial integration with their international peers. In view of this decrease in integration into financial markets, portfolio diversification implementation strategies become feasible.

The results of the non-parametric version of Wright variance testing which includes the Rankings variance and signal ratio scans in the three subperiods. In both cases, statistics were calculated for lags of 2, 4, 8 and 16 days. Given the results of Wright's rankings variance test, random walk hypothesis is rejected in all indexes in the three subperiods. In turn, the signal test also corroborates the rejection of the random walk hypothesis, in all series and in all periods. The results therefore support the conclusion that the random walk hypothesis is not supported by the indices, in periods of crisis and non-crisis. The values of variance ratios are, in all cases, lower than the unit, implying that yields are self-correlated in time, there is a mean-reversion, in all indexes and in all periods, and no differences have been identified between European markets and non-European markets, amongst developed markets and emerging markets, or even among the three analyzed subperiods. The results obtained allow the rejection of the random walk hypothesis and of the financial markets' informational efficiency hypothesis, being consistent with those obtained in other studies, namely those of Richards, Worthington and Higgs, Dsouza and Mallikarjunappa, Hamid, Suleman, Ali Shah and Imdad Akash, Aggarwal, Sadat and Hasan [87, 88, 31, 51, $60,5]$, and, partially, with those of Chaudhuri and $\mathrm{Wu}$, Ngene, Tah and Darrat, Abakah, Alagidede, Mensah and Ohene-Asare and Malafeyev et al. [89, 59, 58, 4].

Mean-reversion process influences the series profitability, which can be called by the overreaction hypothesis, which results in stock prices' extreme movements, which are followed by movements in the opposite direction, to correct the initial overreaction [90].

Under these conditions, markets tend to react excessively to information, ultimately correcting in the following days, whether it is good news or bad news. The high sensitivity of prices upon arrival of new information will have been due to the climate of pessimism and uncertainty experienced by investors during the sample period studied.

The results also suggest that prices do not fully reflect available information and that price changes are not i.i.d.. This has implications for investors, as some profitability may be expected, creating opportunities for arbitrage and abnormal income, contrary to the random walk and informational efficiency assumptions.

\section{Conclusion}

In this essay we investigated financial integration and tested the efficient market hypothesis, in its weak form, in sixteen international financial markets. The sample comprised the period from January 2002 to July 2019, the same being partitioned into three subperiods.

We conducted two statistical tests for this purpose. The first test estimates whether markets have significant levels of financial integration, resulting from the global financial crisis. The second assesses whether price indices show a mean-reversion and test market efficiency, in its weak form.

Regarding the first test, in the subperiod of the pre-global financial crisis, there are 89 pairs of integrated markets with structure break (out of 240 possible). The stock indexes that are most co-integrated are the markets of France and China with 10 integrations (out of 15 possible), while the Thailand market has a single integration.

During the period of the global financial crisis, the results suggest 128 pairs of integrated markets with a structure break. When compared to the pre-crisis subperiod we found that during the global financial crisis the level of financial integration rose $44 \%$. The Hong Kong market is the stock index that cointegrates the most with its peers, 13 integrations (out of 15). The markets in Belgium, France and the USA have 12 integrations, while the financial markets of Ireland, Japan, Greece, Germany and Thailand have 11, 10, 9 and 8 integrations, respectively. The Stock Exchanges of Portugal, Mexico, the Philippines, China and Spain show 7, 6, 5 and 4 integrations, respectively. The financial markets of Brazil and Malaysia are the indices with the least cointegrations of 2 and 1 integrations, respectively.

In the subperiod of the global post-financial crisis, 99 market pairs present financial integration with structural breakdowns. When compared to the period of the global financial crisis we measured that the level of integration decreased by $30 \%$. The financial markets with a higher level of financial integration are the indices of Mexico and Ireland, with 15 and 14 co-integrations respectively (in 15 possible). The Stock Exchanges of Belgium, Portugal, France and the USA have financial integrations with their peers of $13,11,9$ and 7 respectively. The Malaysian and Philippine markets have no financial integration with the other financial markets. Moreover, benchmark markets such as the U.S., Japan and Hong Kong significantly decreased the level of financial integration with their international peers.

In the second test we estimated the non-parametric version of Wright's variance test, which includes the Rankings and Signals Variance Ratios tests for the three subperiods. In both cases, statistics were calculated for lags of 2, 4, 8 and 16 days. Given the results of the variance test by Rankings, the random walk hypothesis is rejected in all indexes and in the three subperiods. In turn, the signal test also corroborates the rejection of the random walk hypothesis, in all series and, in all periods. The results therefore support the conclusion that 
the random walk hypothesis is not supported by the indices, in periods of crisis and non-crisis. Ratios of variance values are, in all cases, lower than the unit, implying that profitability is self-correlated in time and there is meanreversion, indices and in all periods, and no differences have been identified between European markets and non-European markets, between developed markets and emerging markets, or even among the three subperiods scrutinized.

The general conclusion to be retained and sustained in the results obtained, through tests carried out with econometric models, demonstrates that the global financial crisis had a significant impact on the memory properties of financial market indices with a tendency to soften in the last years of the sample. The results indicate that markets are not efficient, in its weak form, that is, the implementation of efficient trading strategies supported by historical prices is advantageous to investors. We measured that the financial integration level decreased significantly in the post-global financial crisis. Additionally, benchmark such as the US, Japan and Hong Kong have noticeably decreased their level of financial integration with their international peers. In view of this significant decrease in financial integration, the implementation of portfolio diversification strategies could be feasible. These findings also make room for market regulators to take steps to ensure better information among international financial markets.

\section{References}

[1] K. J. Forbes and R. Rigobon, "No contagion, only interdependence: Measuring stock market comovements," $J$. Finance, 2002.

[2] R. Dias, J. V. da Silva, and A. Dionísio, "Financial markets of the LAC region: Does the crisis influence the financial integration?," Int. Rev. Financ. Anal., vol. 63, no. January, pp. 160-173, 2019.

[3] Q. Zhang, C. Larkin, and B. M. Lucey, "Universities, knowledge exchange and policy: A comparative study of Ireland and the UK," Sci. Public Policy, 2017.

[4] O. Malafeyev, A. Awasthi, K. S. Kambekar, and A. Kupinskaya, "Random Walks and Market Efficiency in Chinese and Indian Equity Markets," Stat. Optim. Inf. Comput., 2019.

[5] A. R. Sadat and M. E. Hasan, "Testing Weak Form of Market Efficiency of DSE Based on Random Walk Hypothesis Model: A Parametric Test Approach," Int. J. Account. Financ. Report., 2019.

[6] A. K. Tiwari and P. Kyophilavong, "New evidence from the random walk hypothesis for BRICS stock indices: A wavelet unit root test approach," Econ. Model., vol. 43, pp. 38-41, 2014.

[7] K. Hamid, M. T. Suleman, S. Z. Ali Shah, and R. S. Imdad Akash, "Testing the Weak Form of Efficient Market Hypothesis: Empirical Evidence from Asia-Pacific Markets," SSRN Electron. J., vol. 58, no. 58, 2017.

[8] D. S. K. Singh and L. Kumar, "Market Efficiency in Malaysia:
An Empirical Study of Random Walk Hypothesis of Kuala Lumpur Stock Market (Composite Index) Bursa Malaysia," SSRN Electron. J., 2018.

[9] S. Rehman, I. U. Chhapra, M. Kashif, and R. Rehan, "Are Stock Prices a Random Walk? An Empirical Evidence of Asian Stock Markets," ETIKONOMI, 2018.

[10] D. Durusu-Ciftci, M. S. Ispir, and D. Kok, "Do stock markets follow a random walk? New evidence for an old question," Int. Rev. Econ. Financ., 2019.

[11] T. A. Khan, "Cointegration of International Stock Markets: An Investigation of Diversification Opportunities," Undergrad. Econ. Rev., vol. 8, no. 1, p. 52, 2011.

[12] R. Horvath and D. Petrovski, "International stock market integration: Central and south eastern europe compared," Econ. Syst., 2013.

[13] T. Syriopoulos, B. Makram, and A. Boubaker, "Stock market volatility spillovers and portfolio hedging: BRICS and the financial crisis," Int. Rev. Financ. Anal., vol. 39, pp. 7-18, 2015.

[14] A. BenSaïda, "The contagion effect in European sovereign debt markets: A regime-switching vine copula approach," Int. Rev. Financ. Anal., 2017.

[15] S. J. H. Shahzad, R. Ferrer, L. Ballester, and Z. Umar, "Risk transmission between Islamic and conventional stock markets: A return and volatility spillover analysis," Int. Rev. Financ. Anal., vol. 52, pp. 9-26, 2017.

[16] C. Eom and J. W. Park, "Effects of common factors on stock correlation networks and portfolio diversification," Int. Rev. Financ. Anal., vol. 49, pp. 1-11, 2017.

[17] W. G. Choi, T. Kang, G. Y. Kim, and B. Lee, "Global liquidity transmission to emerging market economies, and their policy responses," J. Int. Econ., vol. 109, pp. 153-166, 2017.

[18] J. O. Mensah and G. Premaratne, "Exploring Diversification Benefits in Asia-Pacific Equity Markets," SSRN Electron. J., 2014.

[19] H. G. Grubel, "Internationally diversified portfolios: Welfare gains and capital flows," Am. Econ. Rev., 1968.

[20] H. Levy and M. Sarnat, "International diversification of investment portfolios," Am. Econ. Rev., vol. 60, no. 4, pp. $668-675,1970$.

[21] B. Solnik, C. Boucrelle, and Y. Le Fur, "International market correlation and volatility," Financ. Anal. J., 1996.

[22] M. King, E. Sentana, and S. Wadhwani, "Volatility and Links between National Stock Markets," Econometrica, 2006.

[23] J. Driessen and L. Laeven, "International portfolio diversification benefits: Cross-country evidence from a local perspective,” J. Bank. Financ., 2007.

[24] E. Chang, C. Chen, J. Chi, and M. Young, "IPO underpricing in China: New evidence from the primary and secondary markets," Emerg. Mark. Rev., 2008.

[25] R. Gupta and G. D. Donleavy, "Benefits of diversifying investments into emerging markets with time-varying correlations: An Australian perspective," J. Multinatl. Financ. Manag., vol. 19, no. 2, pp. 160-177, 2009. 
[26] D. Kenourgios and A. Samitas, "Equity market integration in emerging Balkan markets," Res. Int. Bus. Financ., 2011.

[27] D. Gjika and R. Horváth, "Stock market comovements in Central Europe: Evidence from the asymmetric DCC model," Econ. Model., vol. 33, pp. 55-64, 2013.

[28] A. Abu-Alkheil, W. A. Khan, B. Parikh, and S. K. Mohanty, Dynamic co-integration and portfolio diversification of Islamic and conventional indices: Global evidence. Board of Trustees of the University of Illinois, 2016.

[29] A. R. Alotaibi and A. V. Mishra, "Time Varying International Financial Integration for GCC Stock Markets," Q. Rev. Econ. Financ., pp. 1-13, 2016.

[30] P. Ferreira, A. Dionísio, and S. M. S. Movahed, "Assessment of 48 Stock markets using adaptive multifractal approach," Phys. A Stat. Mech. its Appl., vol. 486, pp. 730-750, 2017.

[31] J. J. Dsouza and T. Mallikarjunappa, "Does the Indian Stock Market Exhibit Random Walk?," Paradigm, 2015.

[32] H. Shirvani and N. V. Delcoure, "The random walk in the stock prices of 18 OECD countries: Some robust panel-based integration and cointegration tests," J. Econ. Stud., 2016.

[33] J. M. Poterba and L. H. Summers, "Mean reversion in stock prices. Evidence and Implications," J. financ. econ., 1988.

[34] E. F. Fama and K. R. French, "Dividend yields and expected stock returns," J. financ. econ., 1988.

[35] Lawrence H. Summers, "Does the stock market rationally reflect fundamental values," J. Finance, 1986.

[36] J. L. Urrutia, "TESTS OF RANDOM WALK AND MARKET EFFICIENCY FOR LATIN AMERICAN EMERGING EQUITY MARKETS," J. Financ. Res., 1995.

[37] T. Grieb and M. G. Reyes, "Random walk tests for latin american equity indexes and individual firms," J. Financ. Res., 1999.

[38] A. Charles and O. Darné, "Variance-ratio tests of random walk: An overview," Journal of Economic Surveys. 2009.

[39] M. A. Magnusson and B. Wydick, "How efficient are Africa's emerging stock markets?,” J. Dev. Stud., 2002.

[40] G. Smith, K. Jefferis, and H. J. Ryoo, "African stock markets: Multiple variance ratio tests of random walks," Appl. Financ. Econ., 2002.

[41] B.-N. Huang, "Do Asian stock market prices follow random walks? Evidence from the variance ratio test," Appl. Financ. Econ., 1995.

[42] N. GROENEWOLD and M. ARIFF, “THE EFFECTS OF DEREGULATION ON SHARE-MARKET EFFICIENCY IN THE ASIA-PACIFIC," Int. Econ. J., 2005.

[43] J. H. Kim and A. Shamsuddin, "Are Asian stock markets efficient? Evidence from new multiple variance ratio tests," $J$. Empir. Financ., vol. 15, no. 3, pp. 518-532, 2008.

[44] A. Abraham, F. J. Seyyed, and S. A. Alsakran, "Testing the random walk behavior and efficiency of the gulf stock markets," Financ. Rev., 2002.

[45] O. M. Al-Khazali, D. K. Ding, and C. S. Pyun, "A new variance ratio test of random walk in emerging markets: A revisit," Financ. Rev., 2007.
[46] G. Smith and H. J. Ryoo, "Variance ratio tests of the random walk hypothesis for European emerging stock markets," Eur. J. Financ., vol. 9, no. 3, pp. 290-300, 2003.

[47] A. Worthington and H. Higgs, "Weak-form market efficiency in European emerging and developed stock markets," Sch. Econ. Financ. Discuss. Pap. Work. Pap. Ser. from Sch. Econ. Financ. Queensl. Univ. Technol., 2003.

[48] G. Smith, "Martingales in European emerging stock markets: Size, liquidity and market quality," Eur. J. Financ., 2009.

[49] M. R. Borges, "Efficient market hypothesis in European stock markets," Eur. J. Financ., vol. 16, no. 7, pp. 711-726, 2010.

[50] K. Amira, A. Taamouti, and G. Tsafack, "What drives international equity correlations? volatility or market direction?," J. Int. Money Financ., vol. 30, no. 6, pp. 1234 $1263,2011$.

[51] S. Nisar and M. Hanif, "Testing weak form of efficient market hypothesis: Empirical evidence from South-Asia," World Appl. Sci. J., 2012.

[52] S. Mehla and S. K. Goyal, "Empirical Evidence on Weak Form of Efficiency in Indian Stock Market," Asia-Pacific J. Manag. Res. Innov., 2013.

[53] A. El Khamlichi, K. Sarkar, M. Arouri, and F. Teulon, “Are Islamic equity indices more efficient than their conventional counterparts? Evidence from major global index families," $J$. Appl. Bus. Res., 2014.

[54] V. K. Gimba, "Testing the Weak-form Efficiency Market Hypothesis: Evidence from Nigerian Stock Market," $C B N J$. Appl. Stat., 2012.

[55] R. McKerrow, "Random walks in frontier stock markets," Ghanaian J. Econ., 2013.

[56] K. L. N'DRI, "Variance Ratio Tests of The Random Walk in The BRVM," Appl. Econ. Financ., 2015.

[57] E. J. A. Abakah, P. Alagidede, Lord Mensah, and K. OheneAsare, "Non-linear approach to Random Walk Test in selected African countries," Int. J. Manag. Financ., 2018.

[58] G. Ngene, K. A. Tah, and A. F. Darrat, "The random-walk hypothesis revisited: new evidence on multiple structural breaks in emerging markets," Macroecon. Financ. Emerg. Mark. Econ., 2017.

[59] D. Aggarwal, "Random walk model and asymmetric effect in Korean composite stock price index," Afro-Asian J. Financ. Account., 2018.

[60] A. W. Gregory and B. E. Hansen, "Tests for Cointegration in Models with Regime and Trend Shifts," Oxf. Bull. Econ. Stat., vol. 58, no. 3, pp. 555-560, 1996.

[61] J. Wright, "Alternative variance-ratio tests using ranks and signs," J. Bus. Econ. Stat., vol. 18, no. 1, pp. 1-9, 2000.

[62] D. Dickey and W. Fuller, "Likelihood ratio statistics for autoregressive time series with a unit root," Econometrica, vol. 49, no. 4, pp. 1057-1072, 1981.

[63] D. Kwiatkowski, P. C. B. Phillips, P. Schmidt, and Y. Shinb, "Testing the null hypothesis of stationary against the alternative of a unit root," J. Econom., vol. 54, no. 1, pp. 159178, 1992. 
[64] G. S. Maddala and I.-M. Kim, Unit roots, cointegration, and structural change. Cambridge University Press, 1998.

[65] A. M. Noman and M. Z. Rahman, "Stationarity of South Asian Real Exchange Rates Under Exponential Star (ESTAR) Framework," J. Dev. Areas, vol. 43, no. 2, pp. 41-50, 2010.

[66] J. Clemente, A. Montañés, and M. Reyes, "Testing for a unit root in variables with a double change in the mean," Econ. Lett., vol. 59, no. 2, pp. 175-182, 1998.

[67] P. Perron, "Dealing with structural breaks," Palgrave Handb. Econom., vol. 1, pp. 278-352, 2006.

[68] E. Andreou and E. Ghysels, "Structural Breaks in Financial Time Series," in Handbook of Financial Time Series, 2009, pp. 839-870.

[69] R. F. Engle and C. W. J. Granger, "Co-Integration and Error Correction: Representation, Estimation, and Testing," Econometrica, vol. 55, no. 2, p. 251, 1987.

[70] S. Johansen, "Statistical Analysis of Cointegrated Vectors," $J$. Econ. Dyn. Control, vol. 12, no. 2-3, pp. 231-254, 1988.

[71] B. Seo, "Statistical inference on cointegration rank in error correction models with stationary covariates," J. Econom., vol. 85, pp. 339-385, 1998.

[72] A. Inoue, "Tests of cointegrating rank with a trend-break," $J$. Econom., vol. 90, no. 2, pp. 215-237, 1999.

[73] H. Hansen and S. Johansen, "Recursive Estimation in Cointegrated VAR-Models," Inst. Math. Stat. Univ. Copenhagen Prepr. 19931, 1992.

[74] H. M. Krolzig, "Statistical Analysis of Cointegrated VAR Processes with Markovian Regime Shifts,” Building, 1996.

[75] P. Hansen, "Structural changes in the cointegrated vector autoregressive model," J Econom., vol. 114, no. 2, pp. 261295, 2003.

[76] A. W. Gregory and B. E. Hansen, "Residual-based tests for cointegration in models with regime shifts," J. Econom., vol. 70, no. 1, pp. 99-126, 1996.

[77] E. Zivot and D. W. K. Andrews, "Further Evidence on the Great Crash, the Oil Price Shock, and the Unit Root Hypothesis,” J. Bus. Econ. Stat., vol. 10, no. 3, pp. 251-270, 1992.

[78] A. W. Lo and C. M. A, "Stock Market Prices do not Follow
Random Walks: Evidence from a Simole Specification Test," Rev. Financ. Stud., 1988.

[79] M. Gallegati, "A wavelet-based approach to test for financial market contagion," Comput. Stat. Data Anal., vol. 56, no. 11, pp. 3491-3497, 2012.

[80] P. Horta, C. Mendes, and I. Vieira, "Contagion effects of the subprime crisis in the European NYSE Euronext markets," Port. Econ. J., 2010.

[81] P. C. B. Phillips and J. Yu, "Dating the timeline of financial bubbles during the subprime crisis," Quant. Econom., vol. 2, no. 3, pp. 455-491, 2011.

[82] P. C. B. Phillips and P. Perron, "Testing for a unit root in time series regression," Biometrika, vol. 75, no. 2, pp. 335-346, 1988.

[83] S. Claessens, G. D. Ariccia, D. Igan, and L. Laeven, "Lessons and Policy Implications from the Global Financial Crisis," IMF Work. Pap., pp. 1-40, 2010.

[84] G. Bekaert, M. Ehrmann, M. Fratzscher, and A. Mehl, "Global crises and equity market contagion," Finance, no. May, pp. 123, 2011.

[85] V. Lin, J. Y., Treichel, "The Unexpected Global Financial Crisis Researching Its Root Cause," Policy Res. Work. Pap., no. January, p. 80, 2012.

[86] J. C. A. Teixeira, F. J. F. Silva, M. B. S. Ferreira, and J. A. C. Vieira, "Sovereign credit rating determinants under financial crises," Glob. Financ. J., vol. 36, no. June 2017, pp. 1-13, 2018.

[87] A. J. Richards, "Winner-loser reversals in national stock market indices: Can they be explained?," J. Finance, vol. 52, no. 5, pp. 2129-2144, 1997.

[88] A. C. Worthington and H. Higgs, "Tests of random walks and market efficiency in Latin American stock markets: An empirical note," Pathog. Glob. Health, vol. 107, no. 8, p. 493, 2013.

[89] K. Chaudhuri and Y. Wu, "Random walk versus breaking trend in stock prices: Evidence from emerging markets," $J$. Bank. Financ., vol. 27, no. 4, pp. 575-592, 2003.

[90] W. F. M. De BONDT and R. THALER, "Does the Stock Market Overreact?," J. Finance, vol. 40, no. 3, pp. 793-805, 1985. 